\title{
Redundancy and specificity of multiple trigger factor chaperones in Desulfitobacteria
}

Correspondence

Julien Maillard

julien.maillard@epfl.ch

Received 27 April 2011

Revised 24 May 2011

Accepted 25 May 2011
Julien Maillard, ${ }^{1}$ Pierre Genevaux ${ }^{2}$ and Christof Holliger ${ }^{1}$

${ }^{1}$ Laboratoire de Biotechnologie Environnementale (LBE), Institut d'Ingénierie de l'Environnement (IIE), Ecole Polytechnique Fédérale de Lausanne (EPFL), Lausanne, Switzerland

${ }^{2}$ Laboratoire de Microbiologie et Génétique Moléculaires (LMGM), Centre National de la Recherche Scientifique (CNRS), Université Paul-Sabatier (UPS), Toulouse, France

The ribosome-bound trigger factor (TF) chaperone assists folding of newly synthesized polypeptides and participates in the assembly of macromolecular complexes. In the present study we showed that multiple distinct TF paralogues are present in genomes of Desulfitobacteria, a bacterial genus known for its ability to grow using organohalide respiration. Two full-length TF chaperones and at least one truncated TF (lacking the N-terminal ribosome-binding domain) were identified, the latter being systematically linked to clusters of reductive dehalogenase genes encoding the key enzymes in organohalide respiration. Using a well-characterized heterologous chaperone-deficient Escherichia coli strain lacking both TF and DnaK chaperones, we demonstrated that all three TF chaperones were functional in vivo, as judged by their ability to partially suppress bacterial growth defects and protein aggregation in the absence of both major E. coli chaperones. Next, we found that the N-terminal truncated TF-like protein PceT functions as a dedicated chaperone for the cognate reductive dehalogenase PceA by solubilizing and stabilizing it in the heterologous system. Finally, we showed that PceT specifically interacts with the twin-arginine signal peptide of PceA. Taken together, our data define PceT (and more generally the new RdhT family) as a class of TF-like chaperones involved in the maturation of proteins secreted by the twin-arginine translocation pathway.

\section{INTRODUCTION}

Folding of newly synthesized polypeptides in the cytosol is assisted by molecular chaperones (Hartl \& Hayer-Hartl, 2009). In bacteria, the ribosome-bound chaperone trigger factor (TF) plays a major role in this process. In Escherichia coli, it is believed that most nascent polypeptides emerging from the ribosome interact with TF before completing their folding (Hoffmann et al., 2010; Kramer et al., 2009). TF chaperone specifically binds to L23 protein at the polypeptide exit tunnel of active ribosomes with a $1: 1$ stoichiometry (Ferbitz et al., 2004; Hesterkamp et al., 1996; Kramer et al., 2002b; Patzelt et al., 2001). Remarkably, it has been recently shown that TF cycles the ribosome on and off and that ribosome-free TF may stay bound to

Abbreviations: BTH, bacterial two-hybrid; CTD, C-terminal domain; NTD, $\mathrm{N}$-terminal domain; PCE, perchloroethene/tetrachloroethene; Tat, twinarginine translocation; TF, trigger factor.

The GenBank/EMBL/DDBJ accession number for the trigger factors 1 and 2 (tig1 and -2) sequences of Desulfitobacterium hafniense strain TCEI are GU136801 and GU136802, respectively.

Supplementary methods, three supplementary figures and a supplementary table are available with the online version of this paper. elongating polypeptides for a prolonged period (Kaiser et al., 2006; Rutkowska et al., 2008).

In agreement with such a property, it has recently been proposed that $\mathrm{TF}$ participates in the post-translational assembly of large protein complexes in the cytosol (Martinez-Hackert \& Hendrickson, 2009). The TF chaperone is composed of three distinct protein domains, which have been functionally and structurally determined. The Nterminal domain (NTD) consists of a ribosome-binding domain containing a conserved motif responsible for binding to ribosomal proteins (Hesterkamp et al., 1997; Kramer et al., 2002a, 2004). The central module in the TF structure corresponds to the C-terminal domain (CTD) and harbours the core of the chaperone activity (Genevaux et al., 2004; Kramer et al., 2004). Finally the domain encoded at the centre of the tig gene exhibits a peptidylprolyl cis/trans isomerase (PPIase) activity dispensable for in vivo TF chaperone function (Genevaux et al., 2004). In vivo investigation of $\mathrm{TF}$ functions has revealed that a single tig mutant strain has no observable effect on bacterial growth. In this case it has been proposed that the multifunctional DnaK (Hsp70) chaperone compensates for the lack of TF, thus highlighting the complex interplay between molecular chaperones (Deuerling et al., 1999; 
Genevaux et al., 2004; Liu et al., 2005; Ullers et al., 2007). In agreement with such a hypothesis, the double tig dnaK deletion strain shows a very narrow temperature range of growth and accumulates high levels of aggregated proteins (Deuerling et al., 1999; Genevaux et al., 2004; Teter et al., 1999).

Remarkably we found that several genome sequences of Desulfitobacteria possess two complete TF chaperones and at least one additional TF-like protein that lacks the NTD (J. Maillard, unpublished results, and Morita et al., 2009). Desulfitobacteria belong to the Firmicutes and are obligate anaerobic Gram-positive bacteria known for their metabolic versatility (for a review see Villemur et al., 2006). Pure cultures of Desulfitobacteria have been mostly obtained from environments polluted with chlorinated organic compounds, which they can use as a terminal electron acceptor in a process called organohalide respiration (previously named dehalo- or halorespiration). The key enzyme in this anaerobic respiration is the reductive dehalogenase (RdhA) which builds a large and diverse family of complex redox enzymes harbouring a corrinoid and iron-sulfur clusters as cofactors. RdhAs have been shown to be translocated across the cytoplasmic membrane (John et al., 2006; Suyama et al., 2002), probably via the twin-arginine translocation (Tat) pathway (Sargent, 2007a), strongly indicating that RdhAs need to be fully folded prior to translocation. Our model organism for tetrachloroethene [perchloroethene (PCE)] anaerobic respiration is Desulfitobacterium hafniense strain TCE1 (DhaTCE1) which harbours a conserved four-gene cluster, pceABCT, encoding the PCE reductive dehalogenase (PceA) (Maillard et al., 2005, 2003). The pceT gene encodes a predicted protein of 316 amino acids with sequence homology to CprT which belongs to the chlorophenol reductive dehalogenase $(r d h)$ operon of Desulfitobacterium dehalogenans and which has been shown to share clear sequence homology with the TF (Smidt et al., 2000). Recently a study by Morita et al. (2009) has investigated the PPIase and chaperone activity of PceT from $D$. hafniense strain Y51 using an in vitro approach. Additionally coimmunoprecipitation data have indicated that PceT binds to PceA. Our goal in the present study was to shed light on the functionality of the multiple TF and TF-like chaperones found in Desulfitobacteria with emphasis on the peculiar TFlike protein, PceT, which lacks the NTD. We present the first, to our knowledge, in vivo functional investigation of all three Desulfitobacteria TFs by the use of heterologous complementation in E. coli. Moreover, we provide the evidence on the specific action of PceT in the folding process of PceA. Additionally protein-protein interaction revealed binding of PceT to the Tat signal peptide of PceA. Therefore we propose that PceT and its homologues in other $r d h$ operons represent a class of chaperones dedicated to the family of Tat-dependent reductive dehalogenases.

\section{METHODS}

Bacterial strains and growth conditions. D. hafniense strain TCE1 (here abbreviated DhaTCE1, DSMZ strain 12704) was cultivated in liquid medium in strictly anaerobic conditions using the DSM medium 717 with some modifications: no yeast extract was added and both vitamin solutions (DSM 141 and 503) were combined into a single one. PCE or thiosulfate was added alternatively as terminal electron acceptor. The E. coli strains used in this study are listed in Table 1. E. coli was routinely cultivated in liquid or solid LuriaBertani medium containing the necessary antibiotics: $100 \mu \mathrm{g}$ ampicillin $\mathrm{ml}^{-1}$ (for p29SEN or pUT18 plasmid derivatives), $50 \mu \mathrm{g}$

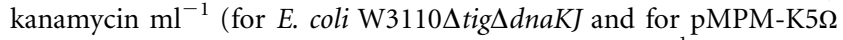
plasmid derivatives) or $30 \mu \mathrm{g}$ chloramphenicol $\mathrm{ml}^{-1}$ (for pT25 plasmid derivatives). In contrast with other E. coli strains, the temperature-sensitive strain $\mathrm{W} 3110 \Delta$ tig $\Delta$ dnaKJ was routinely cultivated at $22{ }^{\circ} \mathrm{C}$. Heat shock transformation of $E$. coli was applied.

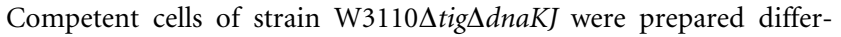
ently. An overnight pre-culture was diluted $50 \times$ in fresh LB medium containing kanamycin and $10 \mathrm{mM} \mathrm{MgSO}_{4}$ and was cultivated to $\mathrm{OD}_{600}$ 0.4. Cells were collected by centrifugation, washed first in onefifth of the initial volume of RF1 solution $[30 \mathrm{mM}$ potassium acetate, $100 \mathrm{mM} \mathrm{RbCl}_{2}, 10 \mathrm{mM} \mathrm{CaCl}_{2}, 50 \mathrm{mM} \mathrm{MnCl}_{2}, 15 \%$ (v/v) glycerol, $\mathrm{pH}$ corrected to 5.8 with acetic acid] and incubated for $20 \mathrm{~min}$ on ice before centrifugation. The cell pellet was resuspended in $1 / 25$ of the initial volume of RF2 solution [10 mM MOPS, $10 \mathrm{mM} \mathrm{RbCl}_{2}, 75 \mathrm{mM}$ $\mathrm{CaCl}_{2}, 15 \%$ (v/v) glycerol, $\mathrm{pH}$ corrected to 6.5 with $\mathrm{KOH}$ ]. Heat shock transformation of strain W3110 $\Delta$ tig $\Delta d n a K J$ was performed for 2 min at $30{ }^{\circ} \mathrm{C}$.

Nucleic acid extraction and amplification. Genomic DNA from DhaTCE1 was extracted using the DNA Tissue kit (Qiagen) and quantified with the Nanodrop ND-1000 apparatus (Thermo Scientific). Total RNA was extracted from DhaTCE1 as described previously (Prat, 2009) (see Supplementary Methods, available with the online version of this paper, for details). A standard $50 \mu \mathrm{l} \mathrm{PCR}$ contained $10 \mu \mathrm{l} \mathrm{GoTaq} 5 \times$ PCR buffer (Promega), $1.5 \mu \mathrm{l} 2.5 \mathrm{mM}$ dNTPs, $2.5 \mu \mathrm{l} 10 \mu \mathrm{M}$ forward and reverse primer solution and $2.5 \mathrm{U}$ GoTaq polymerase (Promega). Reverse transcription of RNA was achieved after $90 \mathrm{~min}$ at $42{ }^{\circ} \mathrm{C}$ in a $30 \mu \mathrm{l}$ reaction containing $500 \mathrm{ng}$ RNA, $1.5 \mu \mathrm{g}$ random hexamer (Microsynth), $6 \mu \mathrm{l}$ M-LMV RT $5 \times$ buffer, $1.25 \mathrm{mM}$ dNTPs (Microsynth) and $300 \mathrm{U}$ M-LMV reverse transcriptase (Promega). Complementary DNA template was diluted between 500- and 5000-fold in order to amplify gene targets in the linear range. These products were finally analysed by the Bioanalyzer (Agilent Technologies) and their intensity was expressed as arbitrary units.

Sequence analysis. Nucleotide and protein sequence analysis was routinely performed with the Lasergene package (DNASTAR). Sequence alignment was performed with CLUSTAL_X (Thompson et al., 1997) and homology trees built with MEGA4 (Tamura et al., 2007).

Nucleotide sequence accession no. The sequence of DhaTCE1 pceT has been previously published (Maillard et al., 2005) and is accessible with the GenBank accession no. AJ439608. Nucleotide sequences of DhaTCE1 full-length trigger factors (tig1 and -2) were submitted to GenBank with the accession nos GU136801 and GU136802, respectively.

Plasmid construction. Plasmids used in this study are summarized in Table 1. Oligonucleotides (Microsynth) and the corresponding restriction enzymes used for cloning are given in Supplementary Table S1 (available with the online version of this paper). Restriction enzymes were used according to the manufacturer's instructions (Promega). Ligation was performed with T4 DNA ligase according to the manufacturer's instructions (Roche). Plasmids were extracted with the QIAprep spin miniprep kit (Qiagen). All constructs were verified by in-house sequencing using the Big Dye Terminator mix v3.1 and the ABI Prism 3100 genetic analyser (Applied Biosystems). Derivatives of plasmid p29SEN (Genevaux et al., 2004) were 
Table 1. Strains and plasmids used in this study

\begin{tabular}{|c|c|c|}
\hline Strains or plasmid Strains & Description & Source or reference \\
\hline D. hafniense strain TCE1 & Strictly anaerobic low-GC Gram-positive & DSM 12704 \\
\hline E. coli DH5a & $\begin{array}{l}\mathrm{F}^{-} \text {endA1 glnV44 thi-1 recA1 relA1 gyrA96 deoR nupG } \phi 80 \mathrm{~d} l a c Z \Delta \mathrm{M} 15 \\
\Delta(\operatorname{lacZYA}-\operatorname{argF}) \mathrm{U} 169, h s d R 17\left(\overline{\mathrm{r}_{\mathrm{k}}} \mathrm{m}_{\mathrm{k}}^{+}\right), \lambda^{-}\end{array}$ & Laboratory strain \\
\hline E. coli $\mathrm{W} 3110$ & $\mathrm{~F}^{-} \lambda^{-} r p h-1 \mathrm{INV}(r r n D, r r n E)$ & Bachmann (1972) \\
\hline E. coli W3110 $\Delta$ tig & E. coli $\mathrm{W} 3110 \Delta \operatorname{tig}\left(\mathrm{Cm}^{\mathrm{S}}\right)$ & Genevaux et al. (2004) \\
\hline E. coli W3110 $\Delta$ tig $\Delta d n a K J$ & E. coli W3110 $\Delta \operatorname{tig}\left(\mathrm{Cm}^{\mathrm{S}}\right) \Delta d n a K d n a J:: \operatorname{Kan}^{\mathrm{R}}$ & Genevaux et al. (2004) \\
\hline E. coli BTH101 & $\mathrm{F}^{-}$, cya-99, araD139 galE15 galK16 rpsL1 $\left(\mathrm{Str}^{\mathrm{r}}\right)$, hsdR2 mcrA1 mcrB1 & Karimova et al. (1998) \\
\hline \multicolumn{3}{|l|}{ Plasmids } \\
\hline p29SEN & Low-copy-number vector, Plac promoter, pSC101 ori & Genevaux et al. (2004) \\
\hline $\mathrm{p} 29-E c o T F$ & E. coli tig gene cloned into p29SEN & Genevaux et al. (2004) \\
\hline p29-PceT & DhaTCE1 pceT gene cloned into p29SEN & This study \\
\hline p29-TF1 & DhaTCE1 tig1 gene cloned into p29SEN & This study \\
\hline p29-TF2 & DhaTCE1 tig2 gene cloned into p29SEN & This study \\
\hline $\mathrm{p} 29-E c o \mathrm{TF}_{\mathrm{N}}::$ PceT & NTD of Eco-TF (1-115) fused to DhaTCE1 PceT (5-316), cloned into p29SEN & This study \\
\hline p29 S-EcoTF & N-terminal Strep version of p29-EcoTF & This study \\
\hline p29 S-PceT & N-terminal Strep version of p29-PceT & This study \\
\hline p29 S-TF1 & N-terminal Strep version of $\mathrm{p} 29-\mathrm{TF} 1$ & This study \\
\hline p29 S-TF2 & N-terminal Strep version of p29-TF2 & This study \\
\hline p29 S-EcoTF $\mathrm{TF}_{\mathrm{N}}:$ PceT & N-terminal Strep version of $\mathrm{p} 29-E c o \mathrm{TF}_{\mathrm{N}}:: \mathrm{PceT}$ & This study \\
\hline $\mathrm{pMPM}-\mathrm{K} 5 \Omega$ & - & Mayer (1995) \\
\hline pMPM-PceA & C-terminal His-tag version of pMPM-K5 $\Omega$ & This study \\
\hline pUT18 & BTH plasmid for X: : Cya18 fusion & Karimova et al. (1998) \\
\hline pT25 & BTH plasmid for Cya25:: X fusion & Karimova et al. (1998) \\
\hline pUT18-PceT & BTH plasmid for PceT:: Cya18 fusion & This study \\
\hline pT25-PceT & BTH plasmid for Cya $25:$ : PceT fusion & This study \\
\hline pUT18-prePceA & BTH plasmid for prePceA: : Cya18 fusion & This study \\
\hline pT25-prePceA & BTH plasmid for Cya25:: prePceA fusion & This study \\
\hline pUT18-PceA & As pUT18-PceA (processed form) & This study \\
\hline pT25-PceA & As pT25-PceA (processed form) & This study \\
\hline pUT18-PSP & BTH plasmid for PceA-signal-peptide: : Cya18 fusion & This study \\
\hline pT25-PSP & BTH plasmid for Cya25:: PceA-signal-peptide fusion & This study \\
\hline pUT18-TF1 & BTH plasmid for TF1 : : Cya18 fusion & This study \\
\hline pT25-TF1 & BTH plasmid for Cya25:: TF1 fusion & This study \\
\hline pUT18-TF2 & BTH plasmid for TF2:: Cya18 fusion & This study \\
\hline pT25-TF2 & BTH plasmid for Cya25:: TF2 fusion & This study \\
\hline
\end{tabular}

constructed to express DhaTCE1 TFs. The same constructs were also prepared including an N-terminal Strep(II) epitope (MASWSHPQFEKIEGR). An additional TF plasmid expressing the hybrid protein $\Phi E c o-\mathrm{TF}_{\mathrm{N}}$ : : PceT was constructed by fusing the NTD of E. coli TF $\left(\mathrm{TF}_{1-115}\right.$, designated Eco- $\left.\mathrm{TF}_{\mathrm{N}}\right)$ to PceT (PceT $\left.\mathrm{P}_{5-316}\right)$ using a PCR fusion method. The native pceA gene including the Tat signal peptide encoding region was cloned into plasmid pMPM-K5 $\Omega$ including the coding sequence for a C-terminal $6 \times$ His tag, giving the plasmid pMPM-PceA. Plasmid constructs for the bacterial twohybrid (BTH) system were constructed in pUT18 and pT25 vectors, from which proteins of interest are expressed as fusion to the T18and T25-fragments of Bordetella petrussis adenylate cyclase (Karimova et al., 1998).

Temperature-sensitive complementation assay of $E$. coli

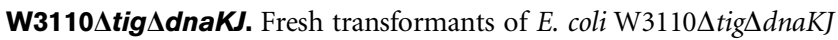
harbouring p29-TF derivatives were cultivated at $22{ }^{\circ} \mathrm{C}$ for $16 \mathrm{~h}$. The cultures were then serially diluted to $10^{-6}$ from which $5 \mu \mathrm{l}$ was spotted on plates containing from 0 to $100 \mu \mathrm{M}$ IPTG. Replica plates were incubated at various temperatures from $22{ }^{\circ} \mathrm{C}$ to $37^{\circ} \mathrm{C}$. The toxicity of

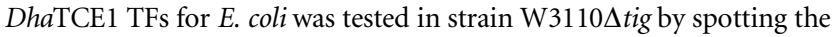
corresponding cultures on plates in the same way.
Isolation of aggregated proteins. Aggregated proteins were isolated from E. coli as described by Tomoyasu et al. (2001). Briefly

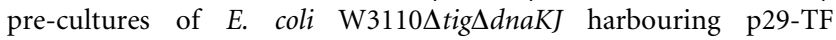
derivatives were diluted $50 \times$ in fresh medium and cultivated at $20{ }^{\circ} \mathrm{C}$ until $\mathrm{OD}_{600} 0.6$ was reached. TF expression was induced after $60 \mathrm{~min}$ by 10,100 or $500 \mu \mathrm{M}$ IPTG. Cultures were then shifted to $37{ }^{\circ} \mathrm{C}$ for $2 \mathrm{~h}$. Cell density was recorded and a culture volume corresponding to $16 \mathrm{OD}_{600}$ units was collected and centrifuged for $10 \mathrm{~min}$ at $4000 \mathrm{~g}$. Cell pellets were resuspended in $120 \mu \mathrm{l}$ freshly prepared buffer A $[10 \mathrm{mM}$ potassium phosphate $(\mathrm{pH} 6.5), 1 \mathrm{mM}$ EDTA, $20 \%$ sucrose, $2 \mathrm{mg}$ lysozyme $\mathrm{ml}^{-1}$ ] and incubated on ice for $30 \mathrm{~min}$. Then $1080 \mu \mathrm{l}$ buffer $\mathrm{B}[10 \mathrm{mM}$ potassium phosphate ( $\mathrm{pH}$ 6.5), $1 \mathrm{mM}$ EDTA] was added and cells were disrupted by sonication $(2 \times 10$ pulses of $1 \mathrm{~s}$ at $30 \mathrm{~W})$. Cell debris were removed by $15 \mathrm{~min}$ centrifugation at $2000 \mathrm{~g}$. The crude extract was centrifuged for $25 \mathrm{~min}$ at $14000 \mathrm{~g}$ and the soluble protein fraction was discarded. Pellets were frozen at $-80{ }^{\circ} \mathrm{C}$ and thawed again, then resuspended in $1 \mathrm{ml}$ buffer B. A new sonication and centrifugation round was done. The pellet was resuspended in $960 \mu \mathrm{l}$ buffer B, sonicated, mixed with $240 \mu \mathrm{l}$ of $10 \%$ Nonidet-P40 and centrifuged again. This extraction of membrane protein was repeated once and the resulting pellet considered as the fraction of aggregated proteins. Samples were 
finally run on $12 \%$ SDS gels and stained with Coomassie blue following standard procedures.

Isolation of TF associated with $E$. coli ribosome. This experiment was performed according to the method of Hesterkamp et al. (1997). E. coli W3110 $\Delta$ tig harbouring the p29-TF Strep(II) derivatives were cultivated at $30{ }^{\circ} \mathrm{C}$ to $\mathrm{OD}_{600} 0.5$. TF expression was induced by $10 \mu \mathrm{M}$ IPTG for $90 \mathrm{~min}$. The cell density was recorded and cultures were kept on ice for $30 \mathrm{~min}$. Cells were harvested by centrifugation for $10 \mathrm{~min}$ at $4000 \mathrm{~g}$ and the pellets were resuspended in a volume of lysis buffer [50 mM Tris/HCl (pH 7.5), $100 \mathrm{mM} \mathrm{NaCl}, 1 \mathrm{mM}$ EDTA, $10 \mathrm{mM}$ $\mathrm{MgCl}_{2}, 15 \%$ sucrose, $2 \mathrm{mg}$ lysozyme $\mathrm{ml}^{-1}$ ] corresponding to half of the $\mathrm{OD}_{600}$ value. After $30 \mathrm{~min}$ on ice, samples were frozen at $-80{ }^{\circ} \mathrm{C}$ and thawed. Four volumes of double-distilled water $\left(\mathrm{ddH}_{2} \mathrm{O}\right)$ were added and cells were disrupted by sonication $(3 \times 10$ pulses of $1 \mathrm{~s})$. Cell debris were removed by centrifugation at $15000 \mathrm{~g}$ for $15 \mathrm{~min}$ and the lysate was collected. In $3 \mathrm{ml}$ ultracentrifugation tubes (Beckman), $0.75 \mathrm{ml}$ lysate was added to $2.25 \mathrm{ml}$ sucrose cushion solution $[20 \mathrm{mM}$ Tris/ $\mathrm{HCl}$ (pH 7.5), $10 \mathrm{mM} \mathrm{MgCl} 2,20 \%$ sucrose, 0.1 or $0.5 \mathrm{M} \mathrm{KCl}$, $0.035 \% \beta$-mercaptoethanol]. After $1 \mathrm{~h}$ of ultracentrifugation at 213000 $\boldsymbol{g}$ the soluble protein fraction (S) was carefully collected. Ribosome pellets (P) were resuspended in $50 \mu \mathrm{l}$ SDS loading buffer. Protein samples were separated by electrophoresis with a ratio of $1: 5(\mathrm{~S}: \mathrm{P})$ and the TFs detected by Western blotting with anti-Strep(II) antibody.

SDS-PAGE and Western blotting. SDS-PAGE and Western blotting were performed following standard procedures (Sambrook et al., 1989). Proteins were then either stained with Coomassie R250 brilliant blue, or transferred onto PVDF membrane using the transblot semi-dry cell according to the manufacturer's instructions (Bio-Rad). Strep(II)-tagged TF derivatives were incubated with antiStrep(II) antibody (Qiagen) and His-tagged PceA with PentaHis antibody (Qiagen), followed by detection with anti-mouse horseradish peroxidase-conjugated secondary antibody (Promega). Standard enhanced chemiluminescence (ECL) detection was performed according to the manufacturer's instructions (GE Healthcare) and revealed on Hyperfilm ECL by a Curix 60 apparatus (AGFA).

\begin{abstract}
Heterologous co-expression of recombinant PceA with TF

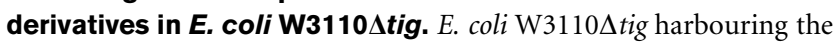
pMPM-PceA plasmid was transformed with all p29-TF derivatives. Cells were cultivated at $37{ }^{\circ} \mathrm{C}$ in $\mathrm{LB}$ to $\mathrm{OD}_{600} 0.5$, and then simultaneous induction of PceA and individual TFs was initiated by adding $0.05 \%$ arabinose and $20 \mu \mathrm{M}$ IPTG, respectively. Induction temperature and times were double-distilled water: $90 \mathrm{~min}$ at $37{ }^{\circ} \mathrm{C}$, $2 \mathrm{~h}$ at $30^{\circ} \mathrm{C}, 6 \mathrm{~h}$ at $20^{\circ} \mathrm{C}$. Soluble and insoluble protein fractions were prepared using a simplified version of the protocol for the isolation of aggregated proteins. Briefly, the volume of induced cells corresponding to $2 \mathrm{OD}_{600}$ units was pelleted. Cells were incubated for $30 \mathrm{~min}$ in $60 \mu \mathrm{l}$ buffer A (see above), after which $340 \mu \mathrm{l}$ buffer B was added. Sonication was performed, followed by removal of cell debris. A $300 \mu \mathrm{l}$ volume of supernatant was centrifuged for $25 \mathrm{~min}$ at 14000 $g$ at $4{ }^{\circ} \mathrm{C}$. The soluble protein fraction (S) was carefully removed and the pellet (insoluble fraction, I) was resuspended in $300 \mu \mathrm{l}$ of $10 \mathrm{mM}$ Tris/HCl buffer ( $\mathrm{pH} 7.5$ ). Finally PceA and Strep(II)-tagged TFderivatives were detected by Western blotting as described above.
\end{abstract}

Protein-protein interaction by the BTH system. After transforming the strain BTH101 with combinations of pT25- and pUT18derivatives, single colonies were picked and cultivated overnight in liquid medium. The next day, $5 \mathrm{ml}$ fresh medium was inoculated with the overnight cultures and cultivated at $30{ }^{\circ} \mathrm{C}$ to $\mathrm{OD}_{600} 0.5$. From there the following two interaction reporter assays were performed.

Colorimetric detection of protein interaction on MacConkeymaltose plates. MacConkey agar (Difco) was prepared as recommended by the manufacturer. While pouring plates, sterile-filtered maltose was added to a final concentration of $1 \%$, in addition to the necessary antibiotics. For each BTH101 derivative, $5 \mu \mathrm{l}$ of the daily culture was spotted in duplicate on MacConkey-maltose plates and incubated for at least $16 \mathrm{~h}$ at $30{ }^{\circ} \mathrm{C}$.

Quantitative measurement of protein interaction by the $\beta$ galactosidase assay. $\mathrm{OD}_{600}$ of daily cultures was recorded and $1 \mathrm{ml}$ of each culture was treated as follows. Cells were permeabilized by the addition of $50 \mu \mathrm{l}$ toluene, vortexed for $30 \mathrm{~s}$ followed by $15 \mathrm{~min}$ incubation on ice. To $450 \mu \mathrm{l} \mathrm{Z}$ buffer $[11$ of $\mathrm{Z}$ buffer contains $8.52 \mathrm{~g}$ $\mathrm{Na}_{2} \mathrm{HPO}_{4}$ (anhydrous), $6.24 \mathrm{~g} \mathrm{NaH}_{2} \mathrm{PO}_{4} .2 \mathrm{H}_{2} \mathrm{O}, 0.75 \mathrm{~g} \mathrm{KCl}, 0.25 \mathrm{~g}$ $\mathrm{MgSO}_{4} .7 \mathrm{H}_{2} \mathrm{O}$ and $0.7 \mathrm{ml}$ freshly added $\beta$-mercaptoethanol], $50 \mu \mathrm{l}$ of permeabilized cells was added and equilibrated at $28{ }^{\circ} \mathrm{C}$ for $5 \mathrm{~min}$. Addition of $100 \mu \mathrm{l}$ ONPG $\left(4 \mathrm{mg} \mathrm{ml}^{-1}\right)$ initiated the enzymic reaction. After a sufficient yellow colour was developed (or after a maximum of $2 \mathrm{~h}$ ), the reaction was stopped by the addition of $250 \mu \mathrm{l}$ $1 \mathrm{M} \mathrm{Na}_{2} \mathrm{CO}_{3}$. Both start and stop times were carefully recorded. After rapid centrifugation to remove cell debris, the $A_{420}$ value of the supernatant was recorded and the $\beta$-galactosidase activity (Miller units $)$ calculated as $\left(A_{420} \times 103\right) /\left(\right.$ time $\times$ volume $\left.\times \mathrm{OD}_{600}\right)$. Time and volume of cells were given in min and $\mathrm{ml}$, respectively.

\section{RESULTS}

\section{Redundancy of TFs in Desulfitobacteria}

A single copy of the TF-encoding gene (tig) was identified in classical bacterial models such as E. coli (Hesterkamp \& Bukau, 1996; Stoller et al., 1995) and Bacillus subtilis (Göthel et al., 1997). In the genome sequence of Desulfitobacteria, however, at least two TF paralogues were identified (see Fig. 1 and Supplementary Fig. S1, available with the online version of this paper). While multiple TFs have been recently reported for D. hafniense strain Y51 (Morita et al., 2009), this trend has not yet been recognized as a general feature of the genus Desulfitobacterium. Two full-length three-domain TFs are encoded in D. hafniense strain Y51 (TF1, DSY3205; TF2, DSY3514), strain DCB-2 (TF1, Dhaf_4378; TF2, Dhaf_1894) and Desulfitobacterium metallireducens (TF1, DesmeDRAFT_0860; TF2, DesmeDRAFT_2807). Specific primers designed based on both tig genes from strain DCB-2 allowed the identification of the corresponding genes from our model organism, DhaTCE1. Both TF paralogues share a high degree of protein sequence identity with those found in the two other strains (100 and $90 \%$, respectively). Only one full-length TF was identified in the draft genomes of D. dehalogenans (DesdeDRAFT_0273) and Desulfitobacterium dichloroeliminans (DesdiDRAFT_1514), indicating that TF2 is not conserved in all Desulfitobacteria and suggesting that this latter protein is not an essential chaperone. Beside the full-length TFs in Desulfitobacteria, several shorter TFs paralogues were also identified in Desulfitobacteria and other organohalide-respiring bacteria such as Dehalobacter restrictus (Maillard et al., 2005) and Geobacter lovleyi as part of gene clusters involved in reductive dechlorination of various chlorinated compounds (see Supplementary Fig. S1 for a complete set). Within this new class of truncated TFs, PceT is encoded in the pce gene cluster of DhaTCE1 and is composed of two of the three classical TF domains, namely the peptidyl-prolyl cis/trans 
isomerase domain and the C-terminal chaperone domain. The N-terminal ribosome-binding domain (E. coli $\mathrm{TF}_{1-118}$ ) is completely missing in this class of TFs; however, the linker region that has been shown to stabilize the CTD (Merz et al., $2006)$ is present and located at the $\mathrm{N}$-terminal end (PceT $\left.\mathrm{P}_{1-22}\right)$. A sequence alignment of all DhaTCE1 TFs is given in Fig. 1 along with E. coli TF and its secondary structure. Gene expression analysis of TFs in DhaTCE1 revealed that under standard anaerobic conditions all three TFs are transcribed at a steady state level with a clear prevalence of TF1 over TF2 (by 100-fold; see Supplementary Fig. S2, available with the online version of this paper).

\section{Desulfitobacterium TFs are partially functional in $E$. coli and exhibit different levels of functionality}

Since no genetic tool is available to investigate the in vivo gene function in Desulfitobacteria, functional complementation was realized by heterologously expressing TFs of DhaTCE1 in the well-characterized E. coli triple mutant strain W3110 $\Delta$ tig $\Delta d n a K J$, in which the genes encoding TF (tig) and both $d n a K$ and $d n a J$ have been deleted (Genevaux et al., 2004). The strain lacking both TF and DnaK chaperones exhibits a strong temperature-sensitive phenotype (Ts) and accumulates high levels of aggregated cytosolic proteins. This strain is considered to be a very sensitive tool to assess TF chaperone function heterologously. For this purpose, all three DhaTCE1 TFs encoding genes were cloned into p29SEN as native genes or with an additional $\mathrm{N}$-terminal Strep(II)-tag to visualize protein expression using anti-strep-tag antibodies. In addition a hybrid protein consisting of the NTD of E. coli TF attached to PceT $\left(\Phi E c o-\mathrm{TF}_{\mathrm{N}}:\right.$ : PceT) was prepared to simulate a full-length TF version of PceT. The plasmid p29-EcoTF expressing E. coli TF (Eco-TF) was included as a positive control throughout.

TF-mediated bacterial growth at high temperature. In order to characterize the TF function in $E$. coli W3110 $\Delta$ tig $\Delta d n a K J$, all three Dha TFs were expressed at increasing IPTG concentrations and the cultures were incubated at permissive and non-permissive temperatures of growth (Fig. 2a). On one hand full-length TFs of Desulfitobacterium (Fig. 2a, lanes 3 and 4) gave the best Ts complementation, although not at the level of E. coli TF. While Dha-TF1 exhibited some toxicity, similarly to EcoTF (Genevaux et al., 2004; Guthrie \& Wickner, 1990), DhaTF2 was not toxic in the limit of experimental conditions and complemented well up to $33^{\circ} \mathrm{C}$. Dha-PceT on the other hand showed a much weaker complementation and at less stringent temperatures. However no toxicity was observed. Remarkably, the hybrid protein $\Phi E c o-\mathrm{TF}_{\mathrm{N}}$ : : PceT

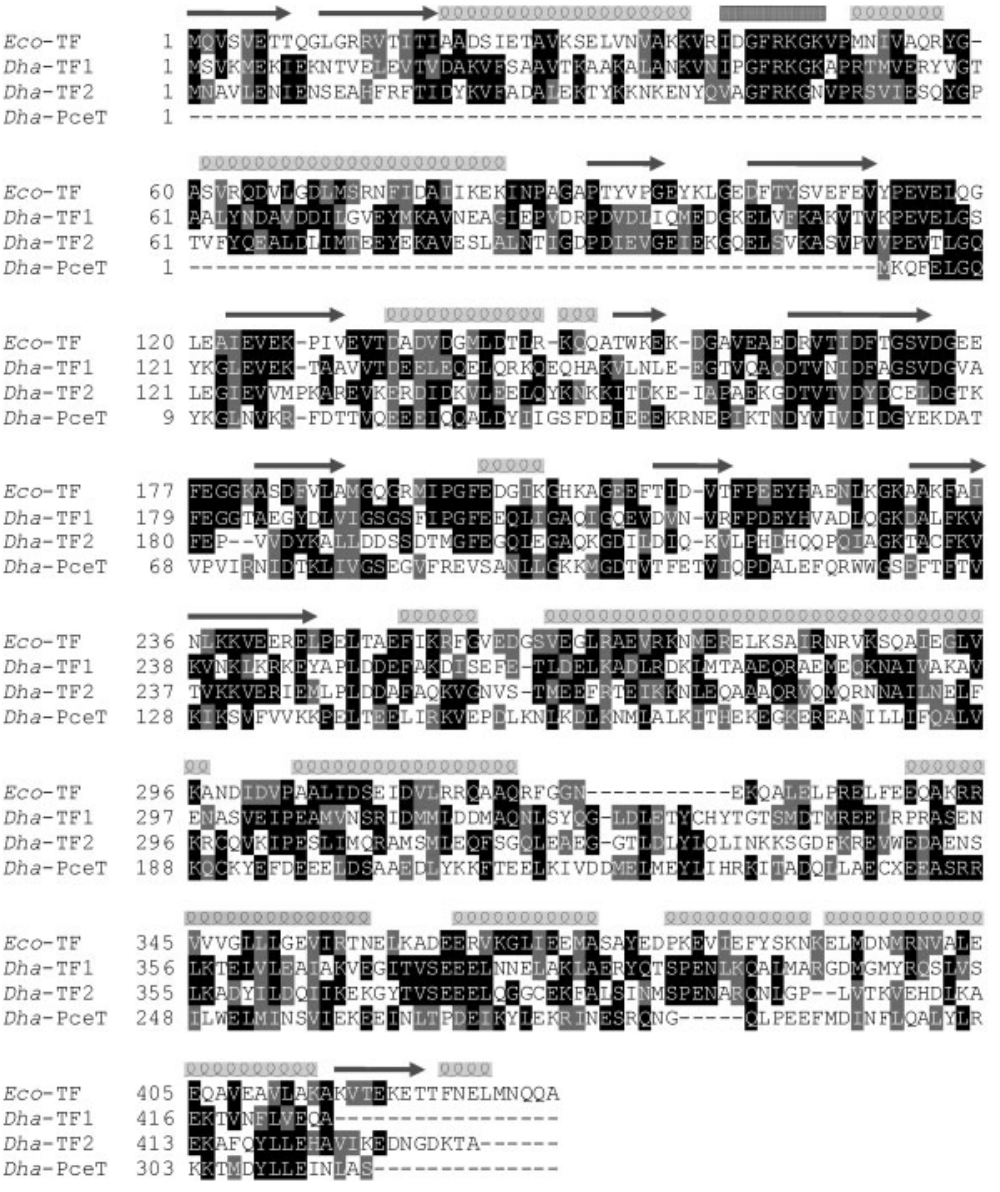

Fig. 1. Protein sequence alignment of Desulfitobacterium TFs. Full-length TFs (DhaTF1 and -TF2) and PceT of DhaTCE1 were aligned with $E$. coli TF by using CLUSTAL_X. The secondary structure of ECO-TF is also indicated: $\alpha$-helices (spirals), $\beta$-strands (arrows) and the conserved motif for ribosome binding (hatched box). 

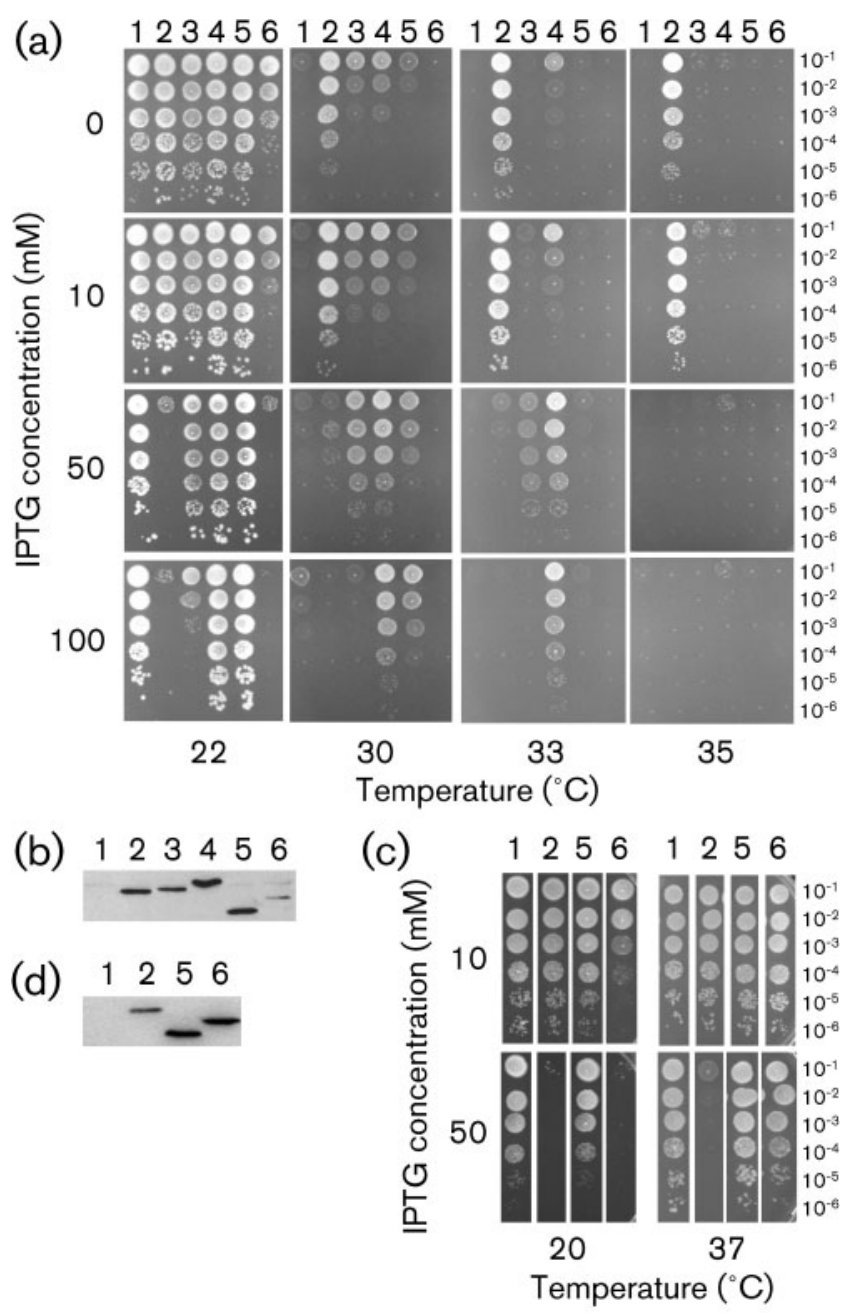

Fig. 2. TF complementation. (a) Complementation of temperature-

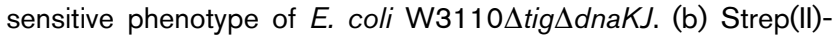
tagged TFs expression level in E. coli W3110 $\Delta$ tig $\Delta d n a K J$ after $1 \mathrm{~h}$ induction at $10 \mu \mathrm{M} \mathrm{IPTG}$ at $20^{\circ} \mathrm{C}$. (c) TF-mediated toxicity in $E$. coli W3110 $\Delta$ tig. Cultures expressing the different TFs were spotted on plates under the conditions and at the concentrations indicated. (d) Strep(II)-tagged TF expression levels in E. coli W3110 $\Delta$ tig after $1 \mathrm{~h}$ induction at $10 \mathrm{mM} \mathrm{IPTG}$ at $20^{\circ} \mathrm{C}$. Sample numbers: 1, vector control; 2, Eco-TF; 3, Dha-TF1; 4, Dha-TF2; 5, Dha-PceT; 6, ФEco-TFF : : PceT.

was highly toxic and thus did not complement the $T s$ phenotype. No complementation was obtained at $35{ }^{\circ} \mathrm{C}$ or above. Very similar results were observed with the Streptagged TFs, which enabled visualization of their expression. With the exception of the hybrid protein all other TFs exhibited a rather similar expression level (Fig. 2b). The slight increased expression of Dha-TF2 might explain why this chaperone could still complement the Ts phenotype at $33{ }^{\circ} \mathrm{C}$. The toxicity of the hybrid protein $\Phi E c o-\mathrm{TF}_{\mathrm{N}}:$ : PceT was further demonstrated by expressing it in the E. coli W3110 $\Delta$ tig background, a strain that does not show the Ts phenotype (Fig. 2c). In this case, the protein was also detrimental at low expression levels but only at the low temperature of $20{ }^{\circ} \mathrm{C}$. Indeed, toxicity was fully relieved at $37{ }^{\circ} \mathrm{C}$. Protein expression was also confirmed under these growth conditions (Fig. 2d).

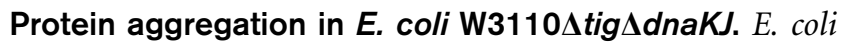
without TF and DnaK chaperones accumulates aggregated proteins when exposed to non-permissive temperature (Genevaux et al., 2004). Complementation of E. coli chaperone mutant strain by DhaTCE1 TFs was also investigated for their ability to relieve the protein aggregation phenotype (Fig. 3). After $1 \mathrm{~h}$ of TF induction with $100 \mu \mathrm{M}$ IPTG at permissive temperature, the cultures were incubated for $2 \mathrm{~h}$ at $37{ }^{\circ} \mathrm{C}$. Protein aggregates were isolated which revealed that Dha-TF1 fully relieved this phenotype compared with the vector control, while Dha-TF2 had only a slight effect. In contrast, Dha-PceT did not prevent aggregation (Fig. 3b). When Dha-TF1 was expressed at a

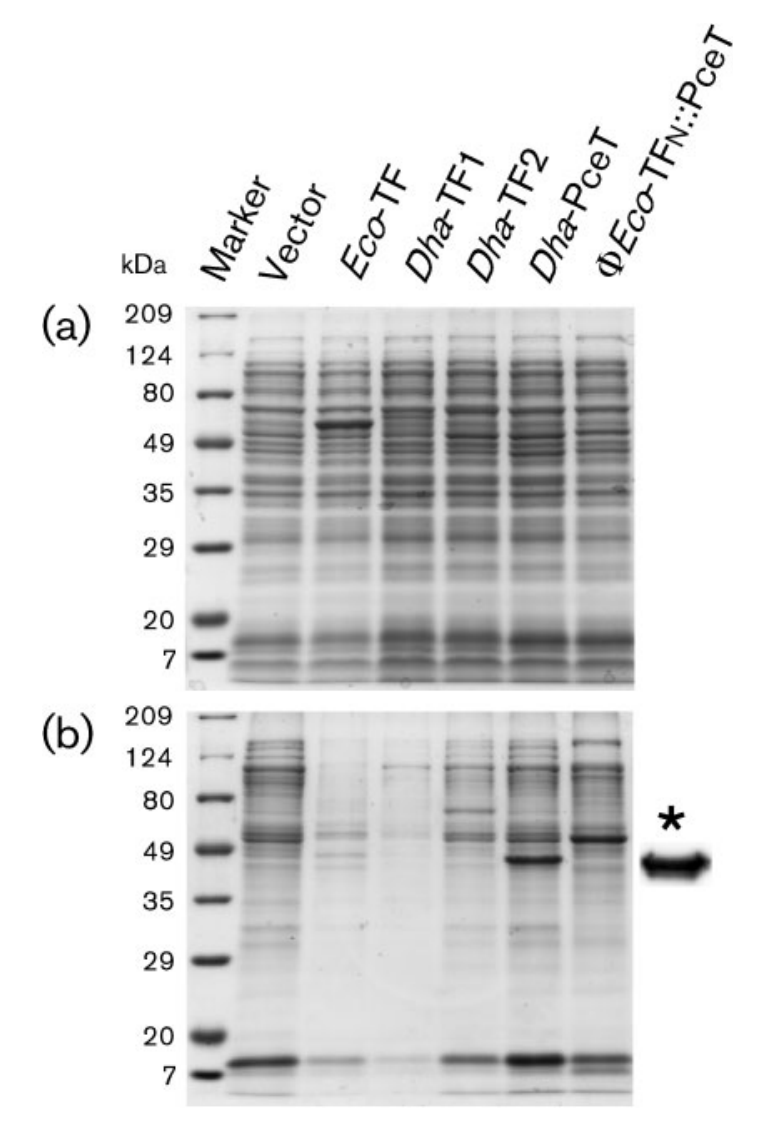

Fig. 3. TF-relieved phenotype of protein aggregation in $E$. coli

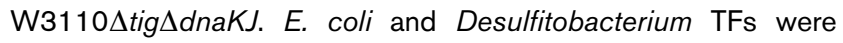
expressed in the $E$. coli deletion strain and protein aggregation was induced by a shift from permissive temperature to $37^{\circ} \mathrm{C}$. (a) Coomassie-stained gel with whole-cell extracts (control) of $E$. coli expressing the TF indicated above. (b) Gel depicting the protein aggregates isolated from the same cells. The asterisk indicates the Strep-tagged Dha-PceT detected by Western blotting in the protein aggregates. 
lower level $(10 \mu \mathrm{M})$, a significantly lower relief was observed, suggesting that a higher level is necessary for Dha-TF1 compared with E. coli TF (data not shown).

TF-mediated secretion delay. Overexpression of E. coli TF has been reported to cause a general secretion delay by sequestering Sec-dependent proteins (Lee \& Bernstein, 2002; Ullers et al., 2007). Such a property of TF was dependent on efficient binding to the ribosome (Ullers et al., 2007). The capacity of Dha-TFs to retard protein export was tested by simultaneous expression of the TFs and the secreted maltose-binding protein (MBP) in E. coli W3110 $\Delta$ tig strain. Secretion delay was observed as an accumulation of the precursor of MBP (upper band in Supplementary Fig. S3, available with the online version of this paper). In contrast with the E. coli TF no secretion delay was observed here for all three Dha-TFs under the conditions used. Only the hybrid $\Phi E c o-\mathrm{TF}_{\mathrm{N}}:$ : PceT, which is expected to strongly bind to ribosomes as it carries E. coli TF NTD, was capable of retarding MBP export.

\section{DhaTCE1 TFs bind differently to $E$. coli ribosomes}

To further characterize the behaviour of TFs from DhaTCE1 in E. coli, their association with ribosomes was investigated using the protocol established by Hesterkamp et al. (1997). Remarkably, the two full-length TFs harbouring a conserved NTD did not behave similarly (Fig. 4). While Dha-TF1 was found as soluble protein as well as associated with the ribosome fraction, showing some KCl-dependent dissociation, Dha-TF2, in contrast, was mostly seen in the soluble fraction. Its slight $\mathrm{KCl}$ dependent dissociation suggested, however, that it binds to E. coli ribosomes with a severely reduced affinity. Almost no Dha-PceT was found in the pelleted ribosome fraction. The weak signal observed there did not show any $\mathrm{KCl}-$ dependent dissociation and might rather represent some aggregated PceT as observed in Fig. 3(b). In contrast, the hybrid PceT protein with the E. coli NTD was strongly retained at the ribosomes similarly to Eco-TF.

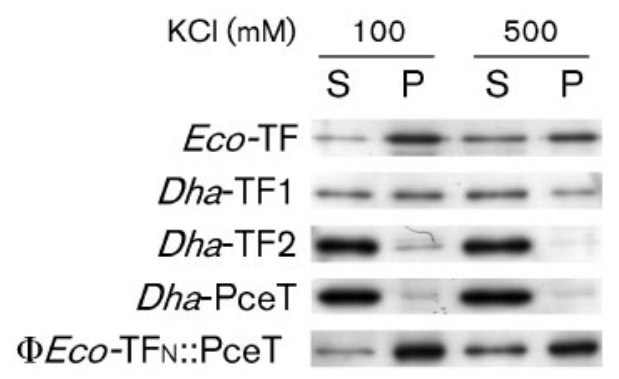

Fig. 4. TF-ribosome interaction. Strep(II)-tagged TFs were induced in E. coli W3110 $\Delta$ tig, then the whole-cell extracts were incubated with 100 or $500 \mathrm{mM} \mathrm{KCl}$, followed by the separation of the soluble protein fraction $(S)$ and the ribosome pellets $(P)$. All tagged TFs were finally detected by Western blotting using antiStrep antibody.

\section{PceT is a dedicated molecular chaperone for the reductive dehalogenase PceA}

In a first attempt to show the dedication of the TF-like protein PceT toward the reductive dehalogenase PceA, gene transcription analysis was investigated in DhaTCE1 following a pulse of PCE in a culture respiring thiosulfate. Samples for RNA extraction were collected at time intervals of $1,2,4$ and $8 \mathrm{~h}$ and the transcription of pceA, pceT and $r p o B$ genes was analysed semiquantitatively by reverse transcription, PCR amplification of serially diluted cDNA and the quantification of PCR products using the Bioanalyzer (Fig. 5). This approach showed first that the
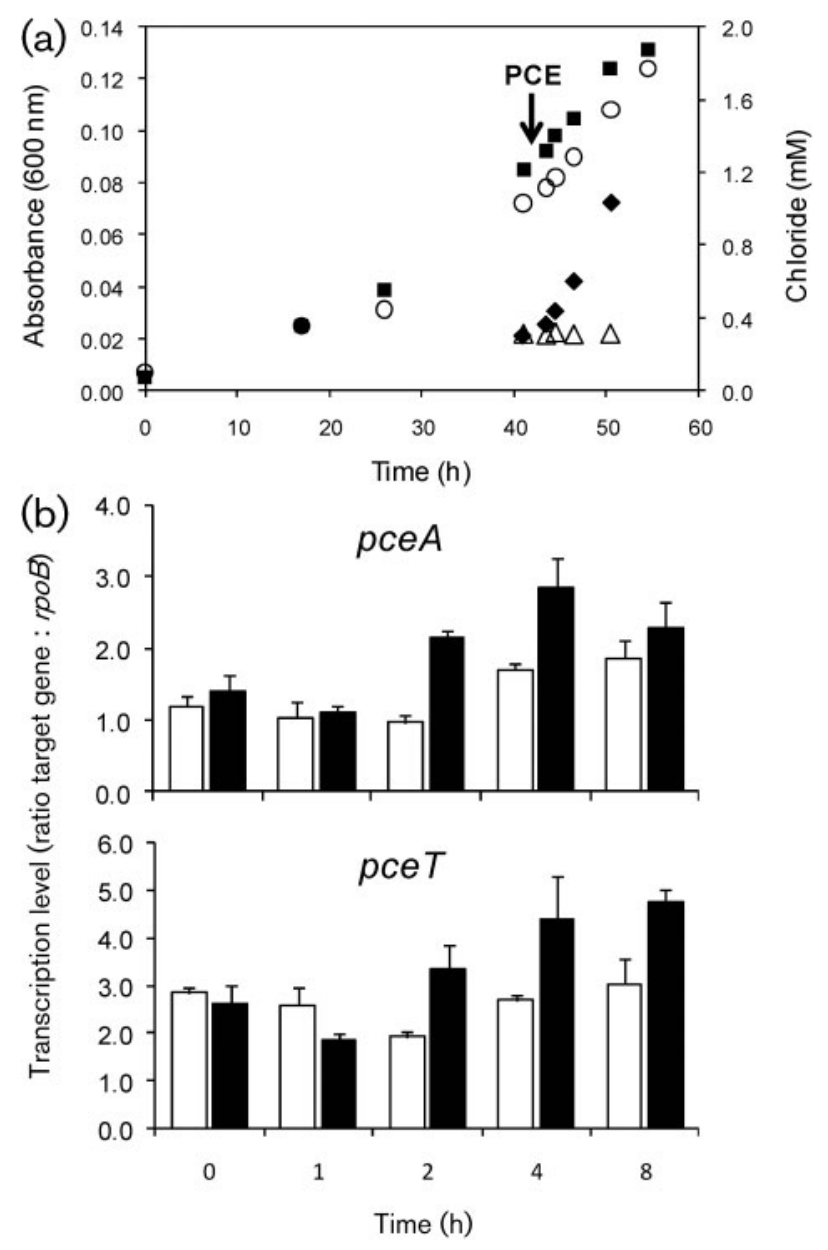

Fig. 5. Gene transcription level of $p c e A$ and $p c e T$ upon addition of PCE. (a) Time-course of DhaTCE1 growth on thiosulfate without (control, $\bigcirc$ ) and with ( $\boldsymbol{\square})$ a PCE pulse. The evolution of chloride release is also depicted for the culture on thiosulfate without PCE $(\triangle)$ and after PCE addition $(\checkmark)$. (b) Gene expression level analysed by combined RT-PCR on serially diluted CDNA and quantification with the Bioanalyzer. Gene transcription is expressed as the ratio of the targeted gene to constitutively expressed rpoB. White bars, expression in DhaTCE1 cultivated on thiosulfate (control); black bars, expression in DhaTCE1 cultivated on thiosulfate after a pulse of PCE (at time 0). Error bars indicate SD. 
reductive dehalogenase (PceA) is active under thiosulfate respiration as chloride release was observed readily after addition of PCE to the culture (Fig. 5a). Moreover, the transcription level of pceA and $p c e T$ increased approximately twofold within a few hours of PCE addition compared with the constitutively expressed $r p o B$ gene.

Previous attempts to produce recombinant reductive dehalogenases in E. coli have shown that the complex redox enzymes are produced as inactive aggregates (A. Duret \& J. Maillard, unpublished data; Kimoto et al., 2010; Neumann et al., 1998; Suyama et al., 2002). Here, we investigated whether PceT is involved in the maturation process of PceA by using the E. coli heterologous system in two independent approaches.

TF-mediated solubilization of the reductive dehalogenase PceA. Heterologous co-expression of a Histagged pre-protein version of PceA together with all TFs was conducted at different induction temperatures in $E$.

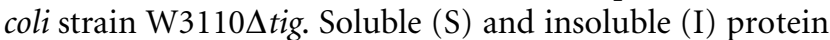
fractions were isolated and assayed for the presence of PceA. The results presented in Fig. 6(a) clearly demonstrated that both Eco-TF and Dha-PceT contributed positively to solubilize recombinant PceA at $37{ }^{\circ} \mathrm{C}$. Indeed percentile signal quantification of soluble versus insoluble PceA (S:I) revealed that PceT led to a $57: 43$ ratio, while a ratio of $45: 55$ was calculated for Eco-TF (Fig. 6a, left panel). Inducing proteins at $30{ }^{\circ} \mathrm{C}$ dramatically shifted PceA toward the soluble fraction. The vector control already showed a clear shift, but co-expression of the chaperones had an even greater effect, with PceT showing the highest S:I ratio $(97: 3$ ) (Fig. 6a, central panel). Further decreasing the induction temperature to $20{ }^{\circ} \mathrm{C}$ had an additional effect as the overall PceA signal was almost absent for the vector control and for Dha-TF1 and -TF2 and only slightly present in the soluble fraction of cells expressing Eco-TF. PceT and, to some extent, also the hybrid protein were still producing large amounts of soluble PceA, suggesting that at $20{ }^{\circ} \mathrm{C}$ PceT is not only solublizing PceA but also preventing its degradation (Fig. 6a, right panel). To further investigate the effect of PceA

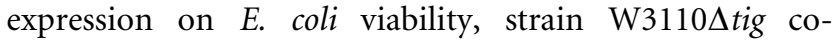
expressing PceA and the chaperones were first cultivated in the absence of inducer then spotted on plates containing different combinations of inducers and incubated at $37{ }^{\circ} \mathrm{C}$ (Fig. 6b) and at 30 and $20^{\circ} \mathrm{C}$ (data not shown). The expression of PceA affected the growth of E. coli at $37{ }^{\circ} \mathrm{C}$, a phenotype which was completely relieved with the coexpression of PceT (Fig. 6b, panel iv, lane 5). No PceAdependent toxicity was observed at a lower temperature, suggesting, together with the partition of PceA in the soluble and insoluble fractions, that PceA aggregation might lead to toxicity towards E. coli growth.

PceA-chaperone interaction revealed by the BTH system. In a second approach, all three DhaTCE1 TF coding sequences, and also the sequences corresponding to

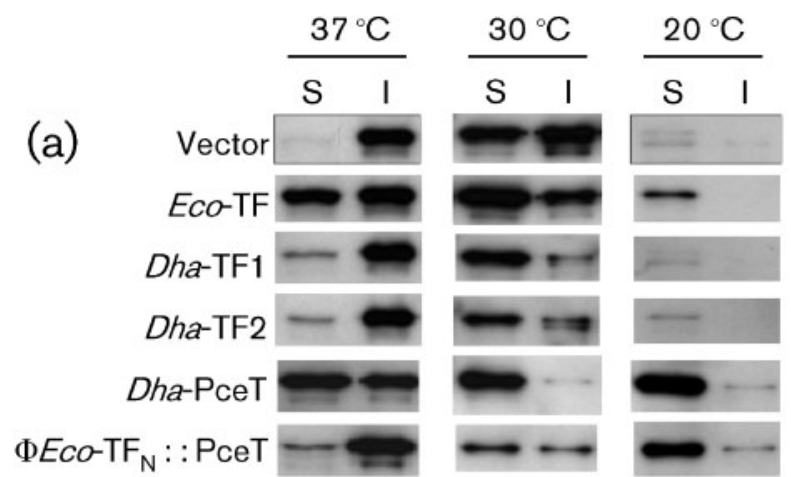

(b)

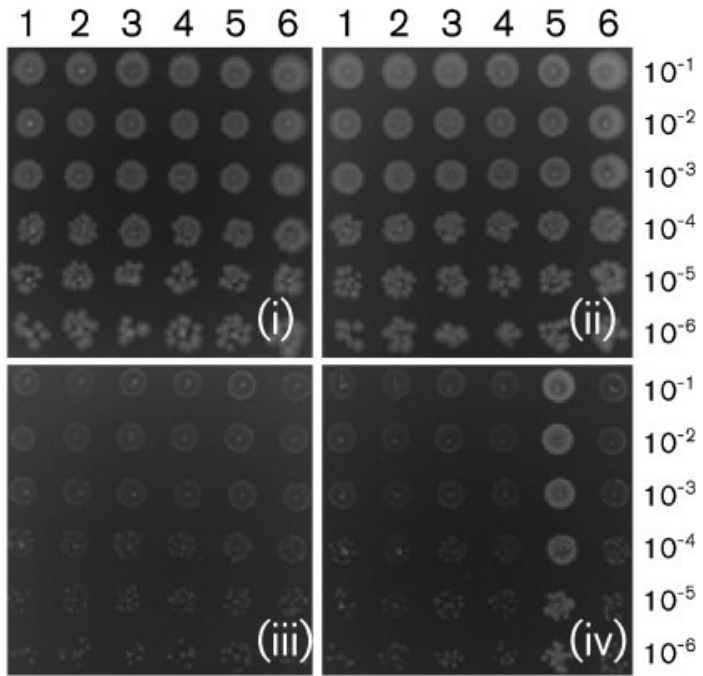

Fig. 6. Heterologous co-expression of PceA together with the different TFs in E. coli W3110 $\Delta$ tig. (a) Effect of TF expression on the solubility of PceA. TFs were induced at $20 \mu \mathrm{M} \mathrm{IPTG,} \mathrm{PceA} \mathrm{at}$ $0.05 \%$ arabinose. Induction temperatures were 37,30 and $20{ }^{\circ} \mathrm{C}$. PceA was detected by Western blotting after separating the soluble (S) and insoluble (I) proteins. (b) Effect of PceA expression on the viability of $E$. coli W3110 $\Delta$ tig by spotting the cultures on plates at $37{ }^{\circ} \mathrm{C}$ without any inducer (i), with $10 \mu \mathrm{M}$ IPTG (ii), with $0.1 \%$ arabinose (iii) or with both inducers (iv). Sample numbering: 1, vector control; 2, Eco-TF; 3, Dha-TF1; 4, Dha-TF2; 5, DhaPceT; 6, ФEco-TF $:$ :PceT.

PceA pre-protein (prePceA, 551 amino acids), its processed form (PceA, 512 aa) and PceA Tat signal peptide (PSP, 36 aa, without the cleavage site), were cloned into BTH vectors pUT18 and pT25. Double transformants of E. coli BTH101 carrying all possible combinations of pUT18 and pT25 derivatives were first spotted on MacConkey-maltose plates to detect protein-protein interaction as red colonies (Fig. 7a). After a stringent incubation of $16 \mathrm{~h}$ only two spots were clearly red, namely (ФPceT : :T18/ФT25 :: PceT) and (ФPceT :: T18/ФT25::PSP). The reciprocal proteins (ФPSP : : T18 and ФT25 : : PceT) did not interact, possibly due to the conformation of individual fusion proteins. Similarly Dha-PceT did not interact with prePceA harbouring the signal peptide suggesting that the Tat 

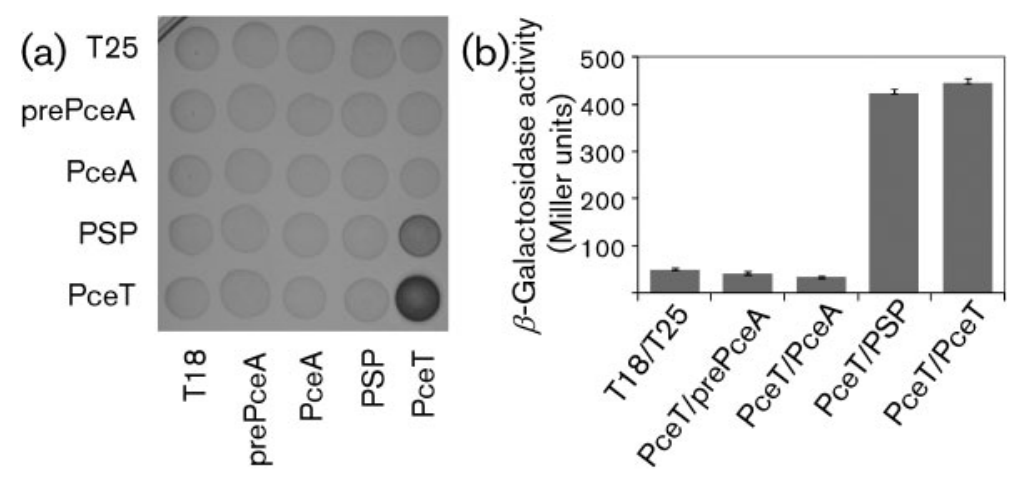

Fig. 7. $T F-P c e A$ interaction by the $B T H$ system. (a) E. coli BTH101 expressing a combination of TFs and various forms of PceA were cultivated on MacConkey-maltose plates. Protein interaction was detected as a red coloration of the colonies (shown here as darker spots). The plasmids expressing the T18- and T25-fusion proteins are given horizontally and vertically, respectively. (b) $\beta$ Galactosidase assay as a reporter for proteinprotein interaction. The name of the interacting proteins are given with the T18-fusion first, followed by the T25-fusion.

signal peptide moiety in the fusion protein $\Phi$ T25 : : prePceA is not accessible to PceT. Nevertheless the positive results obtained here suggested that as for E. coli TF, PceT forms a dimer and that it seems to recognize the Tat signal peptide of PceA. No interaction was observed between the two fulllength Dha-TFs and any form of PceA (data not shown), highlighting the specific nature of PceT-PceA interaction. This qualitative approach was confirmed by assaying the $\beta$ galactosidase activity of cells harbouring all plasmid combinations. A selection of the data obtained is presented in Fig. 7(b).

\section{DISCUSSION}

\section{Multiple TFs in Desulfitobacteria}

Desulfitobacteria is the first genus where multiple paralogues of TF were identified. The analysis of five genome sequences of Desulfitobacteria revealed from two to five TF paralogues, all of them harbouring a conserved full-length TF (TF1) likely to be the general TF chaperone. The genetic context of TF1 contains the gene $c l p X$ in analogy to the context around the tig gene in E. coli. TF2 is encoded by the last gene in a cluster resembling an anaerobic oxidoreductase with unknown function in $D$. hafniense strain Y51 and DCB-2 and part of a molybdoenzyme gene cluster in D. metallireducens, none of these predicted proteins harbouring a Tat signal peptide. In DhaTCE1 the very low gene transcription level observed for tig2 compared with tig1 strongly supports the view that TF1 plays the role of the general molecular chaperone, whereas TF2 might be involved in the maturation of specific proteins under as-yet unknown conditions.

\section{Functionality of Desulfitobacteria full-length TFs}

The Ts phenotype of the E. coli chaperone mutant was significantly relieved by both full-length Dha TFs. However Dha-TF1 allowed Ts complementation to a lower extent than TF2, an observation we can partially explain by its higher affinity for the ribosomes and thus a possible toxicity starting from a relatively lower induction level.
Compared with the conserved ribosome-binding peptide motif in E. coli $\left(\mathrm{G}_{43} \mathrm{FRKGKVP}_{50}\right)$, each Dha TF only differs by a single residue; TF1 harbours an alanine $\left(\mathrm{A}_{49}\right)$, while TF2 has an asparagine residue $\left(\mathrm{N}_{48}\right)$. Although TFribosome structures do not show the direct involvement of $E$. coli $\mathrm{TF}-\mathrm{K}_{48}$ in the interaction with the ribosome (Baram et al., 2005; Ferbitz et al., 2004), this residue could well participate in stabilizing the complex, thus explaining the apparent higher affinity of TF1 for E. coli ribosomes. Protein aggregation was also differently relieved by the two full-length TFs with Dha-TF1 showing a relief similar to $E$. coli TF when expressed at high levels, thus supporting the bona fide general chaperone activity of TF1 in vivo. The weaker complementation exhibited by Dha-TF2 correlates well with the weak ribosome-binding of Dha-TF2. Similarly E. coli TF variants in NTD produce also higher amounts of protein aggregates (Genevaux et al., 2004). This observation further exemplifies the general nature of the Dha-TF1 chaperone.

\section{TF functionality of Dha-PceT}

TF complementation by Dha-PceT and the hybrid protein were more contrasting. Although lacking the full $\mathrm{N}$ terminal ribosome-binding domain PceT showed a weak generic TF function with respect to the Ts phenotype. This is in agreement with the contribution of TF CTD to chaperone activity (Kramer et al., 2004; Merz et al., 2006). Nevertheless, our data support the view of PceT as a remarkable TF-like chaperone with a specific substrate. Indeed, transcription of both $p c e A$ and $p c e T$ genes was induced by PCE although they are produced as distinct mRNA transcripts, as it has been shown for other $r d h$ gene clusters (Futagami et al., 2006; Smidt et al., 2000). Moreover, we demonstrated that PceT acts efficiently in the solubilization of PceA, revealing the prevalence of this unique TF-like chaperone during post-translational folding over the generic action of a housekeeping ribosome-bound TF. PceT retains a functional PPIase activity (Morita et al., 2009) whose contribution remains enigmatic in E. coli TF. In the case of PceT, the PPIase may play a critical role as a folding catalyst as PceA shows a high proline content, i.e. 35 prolines representing $6.4 \%$ of PceA residues, while all 
coding sequences of $D$. hafniense strain Y51 contain an average of $4.1 \%$ prolines. Some general chaperones harbouring a PPIase domain have been shown to interact with the Tat signal peptide of the cofactor-less SufI in E. coli (Holzapfel et al., 2009), further arguing towards the involvement of PceT in chaperoning of Tat substrates. With our co-expression data we also show that at a low temperature PceT prevents the degradation of PceA, which highlights a possible role in quality control. This temperature effect is consistent with observations made in psychrophilic bacteria (Kawamoto et al., 2007; Piette et al., 2010; Qiu et al., 2006), but also in E. coli (Kandror \& Goldberg, 1997), where cold shock experiments have pinpointed the importance of the TF chaperone.

\section{Dedicated chaperone function of Dha-PceT}

In our study, protein interaction data suggest that PceT forms a dimer, an observation that is consistent with several studies on TF dimer formation (Kristensen \& Gajhede, 2003; Liu et al., 2005; Ludlam et al., 2004; Martinez-Hackert \& Hendrickson, 2007, 2009; Patzelt et al., 2002). Both NTD and CTD of TF have been shown to participate in dimerization, however, with conflicting orientations (Kristensen \& Gajhede, 2003; MartinezHackert \& Hendrickson, 2007; Patzelt et al., 2002). As PceT has no NTD, it is remarkable that it is able to form dimers. The presence in PceT of the linker region connecting TF NTD to the PPIase domain (MartinezHackert \& Hendrickson, 2009; Yao et al., 2008) suggests that together with the CTD, the linker region represents the minimal structure allowing dimerization. In a recent report on the participation of the TF dimer in the assembly of large protein complexes it is proposed that TF is not only involved in co-translational protein folding but may also participate in assembly of large molecular complexes (Martinez-Hackert \& Hendrickson, 2009). The PceT dimer could thus serve for similar purpose to the benefit of the complex redox enzyme PceA.

The mode of action of PceT resembles that of other chaperones involved in the maturation of Tat-dependent proteins such as TorD (Genest et al., 2009; Sargent, 2007b), DmsD (Guymer et al., 2009; Li et al., 2010) or NapD proteins (Kern et al., 2007; Maillard et al., 2007; Potter \& Cole, 1999). Although belonging to very distinct protein families, these chaperones specifically recognize the signal peptide of their cognate Tat-dependent protein and participate in their maturation process. Likewise, PceT binds to the Tat signal peptide of PceA and thus probably retards its translocation, allowing both folding and cofactor assembly of the reductive dehalogenase. Whether additional chaperones are required for complete maturation of PceA is not yet known. Considering PceT and its homologues in other reductive dehalogenase gene clusters, we propose to give the general name of RdhT to this class of dedicated TF-like Tat chaperones. Not only do they represent a new chaperone family in Tat proofreading, but they also indicate a subtle evolutionary strategy developed by organohalide-respiring bacteria to transform a general TF chaperone into a dedicated one by losing its $\mathrm{N}$-terminal ribosome-binding domain to avoid interference with the generic ribosome-bound $\mathrm{TF}$ and by evolving toward a specific substrate.

\section{Conclusions}

The functional redundancy of TFs in Desulfitobacteria is revealed to be only apparent as each TF seems to have its own role in the metabolism, although all of them share some general chaperone functionalities. While Dha-TF1 represents the general TF chaperone in Desulfitobacteria, no metabolic function could yet be assigned to TF2. Finally we can consider PceT as the paradigmatic member of a new class of Tat chaperones harbouring strong similarities with $\mathrm{TF}$, which confirms that several evolutionary strategies have converged toward a unified goal of dedicated chaperones in the Tat machinery (Sargent, 2007a), namely to allow quality control of the folding state of Tat substrates prior to their translocation across the cytoplasmic membrane.

\section{ACKNOWLEDGEMENTS}

This study was partly made possible thanks to a short-term fellowship from the European Molecular Biology Organization (EMBO) (ASTF 80.00-2008) allowing J. M. to travel to and work in P. G'.s laboratory. P. G. is supported by Action Temporaire Incitative Sur ProgrammeCentre National de la Recherche Scientifique (ATIP-CNRS) Microbiology and the Region Midi-Pyrénées. We would like to thank Marion Blondeau for technical assistance and Nevenka Adler for critical reading of the manuscript.

\section{REFERENCES}

Bachmann, B. J. (1972). Pedigrees of some mutant strains of Escherichia coli K-12. Bacteriol Rev 36, 525-557.

Baram, D., Pyetan, E., Sittner, A., Auerbach-Nevo, T., Bashan, A. \& Yonath, A. (2005). Structure of trigger factor binding domain in biologically homologous complex with eubacterial ribosome reveals its chaperone action. Proc Natl Acad Sci U S A 102, 12017-12022.

Deuerling, E., Schulze-Specking, A., Tomoyasu, T., Mogk, A. \& Bukau, B. (1999). Trigger factor and DnaK cooperate in folding of newly synthesized proteins. Nature 400, 693-696.

Ferbitz, L., Maier, T., Patzelt, H., Bukau, B., Deuerling, E. \& Ban, N. (2004). Trigger factor in complex with the ribosome forms a molecular cradle for nascent proteins. Nature 431, 590-596.

Futagami, T., Yamaguchi, T., Nakayama, S., Goto, M. \& Furukawa, K. (2006). Effects of chloromethanes on growth of and deletion of the pce gene cluster in dehalorespiring Desulfitobacterium hafniense strain Y51. Appl Environ Microbiol 72, 5998-6003.

Genest, O., Méjean, V. \& lobbi-Nivol, C. (2009). Multiple roles of TorD-like chaperones in the biogenesis of molybdoenzymes. FEMS Microbiol Lett 297, 1-9.

Genevaux, P., Keppel, F., Schwager, F., Langendijk-Genevaux, P. S., Hartl, F. U. \& Georgopoulos, C. (2004). In vivo analysis of the overlapping functions of DnaK and trigger factor. EMBO Rep 5, 195-200. 
Göthel, S. F., Schmid, R., Wipat, A., Carter, N. M., Emmerson, P. T., Harwood, C. R. \& Marahiel, M. A. (1997). An internal FK506-binding domain is the catalytic core of the prolyl isomerase activity associated with the Bacillus subtilis trigger factor. Eur J Biochem 244, 59-65.

Guthrie, B. \& Wickner, W. (1990). Trigger factor depletion or overproduction causes defective cell division but does not block protein export. J Bacteriol 172, 5555-5562.

Guymer, D., Maillard, J. \& Sargent, F. (2009). A genetic analysis of in vivo selenate reduction by Salmonella enterica serovar Typhimurium LT2 and Escherichia coli K12. Arch Microbiol 191, 519-528.

Hartl, F. U. \& Hayer-Hartl, M. (2009). Converging concepts of protein folding in vitro and in vivo. Nat Struct Mol Biol 16, 574-581.

Hesterkamp, T. \& Bukau, B. (1996). The Escherichia coli trigger factor. FEBS Lett 389, 32-34.

Hesterkamp, T., Hauser, S., Lütcke, H. \& Bukau, B. (1996). Escherichia coli trigger factor is a prolyl isomerase that associates with nascent polypeptide chains. Proc Natl Acad Sci U S A 93, 4437-4441.

Hesterkamp, T., Deuerling, E. \& Bukau, B. (1997). The aminoterminal 118 amino acids of Escherichia coli trigger factor constitute a domain that is necessary and sufficient for binding to ribosomes. J Biol Chem 272, 21865-21871.

Hoffmann, A., Bukau, B. \& Kramer, G. (2010). Structure and function of the molecular chaperone Trigger Factor. Biochim Biophys Acta 1803, 650-661.

Holzapfel, E., Moser, M., Schiltz, E., Ueda, T., Betton, J. M. \& Müller, M. (2009). Twin-arginine-dependent translocation of Sufl in the absence of cytosolic helper proteins. Biochemistry 48, 5096-5105.

John, M., Schmitz, R. P., Westermann, M., Richter, W. \& Diekert, G. (2006). Growth substrate dependent localization of tetrachloroethene reductive dehalogenase in Sulfurospirillum multivorans. Arch Microbiol 186, 99-106.

Kaiser, C. M., Chang, H. C., Agashe, V. R., Lakshmipathy, S. K., Etchells, S. A., Hayer-Hartl, M., Hartl, F. U. \& Barral, J. M. (2006). Real-time observation of trigger factor function on translating ribosomes. Nature 444, 455-460.

Kandror, O. \& Goldberg, A. L. (1997). Trigger factor is induced upon cold shock and enhances viability of Escherichia coli at low temperatures. Proc Natl Acad Sci U S A 94, 4978-4981.

Karimova, G., Pidoux, J., Ullmann, A. \& Ladant, D. (1998). A bacterial two-hybrid system based on a reconstituted signal transduction pathway. Proc Natl Acad Sci U S A 95, 5752-5756.

Kawamoto, J., Kurihara, T., Kitagawa, M., Kato, I. \& Esaki, N. (2007). Proteomic studies of an Antarctic cold-adapted bacterium, Shewanella livingstonensis Ac10, for global identification of coldinducible proteins. Extremophiles 11, 819-826.

Kern, M., Mager, A. M. \& Simon, J. (2007). Role of individual nap gene cluster products in NapC-independent nitrate respiration of Wolinella succinogenes. Microbiology 153, 3739-3747.

Kimoto, H., Suye, S., Makishima, H., Arai, J., Yamaguchi, S., Fujii, Y., Yoshioka, T. \& Taketo, A. (2010). Cloning of a novel dehalogenase from environmental DNA. Biosci Biotechnol Biochem 74, 1290-1292.

Kramer, G., Ramachandiran, V., Horowitz, P. M. \& Hardesty, B. (2002a). The molecular chaperone DnaK is not recruited to translating ribosomes that lack trigger factor. Arch Biochem Biophys 403, 63-70.

Kramer, G., Rauch, T., Rist, W., Vorderwülbecke, S., Patzelt, H., Schulze-Specking, A., Ban, N., Deuerling, E. \& Bukau, B. (2002b). L23 protein functions as a chaperone docking site on the ribosome. Nature 419, 171-174.

Kramer, G., Rutkowska, A., Wegrzyn, R. D., Patzelt, H., Kurz, T. A., Merz, F., Rauch, T., Vorderwülbecke, S., Deuerling, E. \& Bukau, B.
(2004). Functional dissection of Escherichia coli trigger factor: unraveling the function of individual domains. J Bacteriol 186, 3777-3784.

Kramer, G., Boehringer, D., Ban, N. \& Bukau, B. (2009). The ribosome as a platform for co-translational processing, folding and targeting of newly synthesized proteins. Nat Struct Mol Biol 16, 589597.

Kristensen, O. \& Gajhede, M. (2003). Chaperone binding at the ribosomal exit tunnel. Structure 11, 1547-1556.

Lee, H. C. \& Bernstein, H. D. (2002). Trigger factor retards protein export in Escherichia coli. J Biol Chem 277, 43527-43535.

Li, H., Chang, L., Howell, J. M. \& Turner, R. J. (2010). DmsD, a Tat system specific chaperone, interacts with other general chaperones and proteins involved in the molybdenum cofactor biosynthesis. Biochim Biophys Acta 1804, 1301-1309.

Liu, C. P., Perrett, S. \& Zhou, J. M. (2005). Dimeric trigger factor stably binds folding-competent intermediates and cooperates with the DnaK-DnaJ-GrpE chaperone system to allow refolding. J Biol Chem 280, 13315-13320.

Ludlam, A. V., Moore, B. A. \& Xu, Z. (2004). The crystal structure of ribosomal chaperone trigger factor from Vibrio cholerae. Proc Natl Acad Sci U S A 101, 13436-13441.

Maillard, J., Schumacher, W., Vazquez, F., Regeard, C., Hagen, W. R. \& Holliger, C. (2003). Characterization of the corrinoid iron-sulfur protein tetrachloroethene reductive dehalogenase of Dehalobacter restrictus. Appl Environ Microbiol 69, 4628-4638.

Maillard, J., Regeard, C. \& Holliger, C. (2005). Isolation and characterization of $T n$-Dhal, a transposon containing the tetrachloroethene reductive dehalogenase of Desulfitobacterium hafniense strain TCE1. Environ Microbiol 7, 107-117.

Maillard, J., Spronk, C. A., Buchanan, G., Lyall, V., Richardson, D. J., Palmer, T., Vuister, G. W. \& Sargent, F. (2007). Structural diversity in twin-arginine signal peptide-binding proteins. Proc Natl Acad Sci U S A 104, 15641-15646.

Martinez-Hackert, E. \& Hendrickson, W. A. (2007). Structures of and interactions between domains of trigger factor from Thermotoga maritima. Acta Crystallogr D Biol Crystallogr 63, 536-547.

Martinez-Hackert, E. \& Hendrickson, W. A. (2009). Promiscuous substrate recognition in folding and assembly activities of the trigger factor chaperone. Cell 138, 923-934.

Mayer, M. P. (1995). A new set of useful cloning and expression vectors derived from pBlueScript. Gene 163, 41-46.

Merz, F., Hoffmann, A., Rutkowska, A., Zachmann-Brand, B., Bukau, B. \& Deuerling, E. (2006). The C-terminal domain of Escherichia coli trigger factor represents the central module of its chaperone activity. J Biol Chem 281, 31963-31971.

Morita, Y., Futagami, T., Goto, M. \& Furukawa, K. (2009). Functional characterization of the trigger factor protein PceT of tetrachloroethenedechlorinating Desulfitobacterium hafniense Y51. Appl Microbiol Biotechnol 83, 775-781.

Neumann, A., Wohlfarth, G. \& Diekert, G. (1998). Tetrachloroethene dehalogenase from Dehalospirillum multivorans: cloning, sequencing of the encoding genes, and expression of the pceA gene in Escherichia coli. J Bacteriol 180, 4140-4145.

Patzelt, H., Rüdiger, S., Brehmer, D., Kramer, G., Vorderwülbecke, S., Schaffitzel, E., Waitz, A., Hesterkamp, T., Dong, L. \& other authors (2001). Binding specificity of Escherichia coli trigger factor. Proc Natl Acad Sci U S A 98, 14244-14249.

Patzelt, H., Kramer, G., Rauch, T., Schönfeld, H. J., Bukau, B. \& Deuerling, E. (2002). Three-state equilibrium of Escherichia coli trigger factor. Biol Chem 383, 1611-1619. 
Piette, F., D’Amico, S., Struvay, C., Mazzucchelli, G., Renaut, J., Tutino, M. L., Danchin, A., Leprince, P. \& Feller, G. (2010). Proteomics of life at low temperatures: trigger factor is the primary chaperone in the Antarctic bacterium Pseudoalteromonas haloplanktis TAC125. Mol Microbiol 76, 120-132.

Potter, L. C. \& Cole, J. A. (1999). Essential roles for the products of the napABCD genes, but not napFGH, in periplasmic nitrate reduction by Escherichia coli K-12. Biochem J 344, 69-76.

Prat, L. (2009). Identification and characterization of proteins supporting dehalorespiration in Desulfitobacterium hafniense strain TCE1. PhD thesis, École Polytechnique Fédérale de Lausanne, Switzerland.

Qiu, Y., Kathariou, S. \& Lubman, D. M. (2006). Proteomic analysis of cold adaptation in a Siberian permafrost bacterium - Exiguobacterium sibiricum $255-15$ by two-dimensional liquid separation coupled with mass spectrometry. Proteomics 6, 5221-5233.

Rutkowska, A., Mayer, M. P., Hoffmann, A., Merz, F., ZachmannBrand, B., Schaffitzel, C., Ban, N., Deuerling, E. \& Bukau, B. (2008). Dynamics of trigger factor interaction with translating ribosomes. J Biol Chem 283, 4124-4132.

Sambrook, J., Fritsch, E. F. \& Maniatis, T. (1989). Molecular Cloning: a Laboratory Manual, 2nd edn. Cold Spring Harbor, NY: Cold Spring Harbor Laboratory.

Sargent, F. (2007a). The twin-arginine transport system: moving folded proteins across membranes. Biochem Soc Trans 35, 835-847.

Sargent, F. (2007b). Constructing the wonders of the bacterial world: biosynthesis of complex enzymes. Microbiology 153, 633-651.

Smidt, H., van Leest, M., van der Oost, J. \& de Vos, W. M. (2000). Transcriptional regulation of the $c p r$ gene cluster in ortho-chlorophenol-respiring Desulfitobacterium dehalogenans. J Bacteriol 182, 5683-5691.
Stoller, G., Rücknagel, K. P., Nierhaus, K. H., Schmid, F. X., Fischer, G. \& Rahfeld, J. U. (1995). A ribosome-associated peptidyl-prolyl cis/trans isomerase identified as the trigger factor. EMBO J 14, 4939-4948.

Suyama, A., Yamashita, M., Yoshino, S. \& Furukawa, K. (2002). Molecular characterization of the PceA reductive dehalogenase of Desulfitobacterium sp. strain Y51. J Bacteriol 184, 3419-3425.

Tamura, K., Dudley, J., Nei, M. \& Kumar, S. (2007). MEGA4: Molecular Evolutionary Genetics Analysis (MEGA) software version 4.0. Mol Biol Evol 24, 1596-1599.

Teter, S. A., Houry, W. A., Ang, D., Tradler, T., Rockabrand, D., Fischer, G., Blum, P., Georgopoulos, C. \& Hartl, F. U. (1999). Polypeptide flux through bacterial Hsp70: DnaK cooperates with trigger factor in chaperoning nascent chains. Cell 97, 755-765.

Thompson, J. D., Gibson, T. J., Plewniak, F., Jeanmougin, F. \& Higgins, D. G. (1997). The CLUSTAL_X windows interface: flexible strategies for multiple sequence alignment aided by quality analysis tools. Nucleic Acids Res 25, 4876-4882.

Tomoyasu, T., Mogk, A., Langen, H., Goloubinoff, P. \& Bukau, B. (2001). Genetic dissection of the roles of chaperones and proteases in protein folding and degradation in the Escherichia coli cytosol. Mol Microbiol 40, 397-413.

Ullers, R. S., Ang, D., Schwager, F., Georgopoulos, C. \& Genevaux, P. (2007). Trigger Factor can antagonize both SecB and DnaK/DnaJ chaperone functions in Escherichia coli. Proc Natl Acad Sci U S A 104, 3101-3106.

Villemur, R., Lanthier, M., Beaudet, R. \& Lépine, F. (2006). The Desulfitobacterium genus. FEMS Microbiol Rev 30, 706-733.

Yao, Y., Bhabha, G., Kroon, G., Landes, M. \& Dyson, H. J. (2008). Structure discrimination for the C-terminal domain of Escherichia coli trigger factor in solution. J Biomol NMR 40, 23-30.

Edited by: F. Sargent 